\title{
Notes of a Translator on Bogatyrev's Monograph: Magical Acts, Rites, and Beliefs of Subcarpathian Rus'
}

\section{Patricia A. Krafcik, Evergreen State College}

Petr Grigorevich Bogatyrev was without question one of the most significant Russian folklorists of the twentieth century. His participation in the organization and activity of the Moscow Linguistic Circle which, along with the Petrograd Society for the Study of Poetic Language, gave birth to the Russian Formalist School, and his subsequent work with the Prague Linguistic Circle nurtured his own pioneering interests and activities in the field of ethnography. His life in Stalinist Russia was, naturally, not without tragedy. He suffered immensely as a result of his work "abroad" as a translator for the Soviet embassy in Prague between 1922-1939, as well as for his association with "foreign folklorists," among them his compatriot Roman Jakobson who chose to immigrate to the United States on the eve of the Nazi invasion of Czechoslovakia while Bogatyrev returned home to Russia.

Amidst the valuable pieces of scholarship he left behind are his studies of Rusyn folklore from the Carpathian Mountains, which he researched in a series of field expeditions during the 1920s and 1930s. Of these, the greatest gem is his monograph entitled Magical Acts. Rites, and Beliefs in Subcarpathian Rus', published initially in a French translation by the Institute of Slavic Studies (Institut d'etudes slaves) in Paris in 1929 (Actes Magigues, rites et crovances en Russie subcarpathique). Here, he succeeded in describing what in the 1920 s was still, as he stated in his diary, one of the most archaic of Slavic peasant cultures. The relative isolation of the region with its scattered mountain villages allowed for the survival of traditional folklore and for the perpetuation of ritual and magical practices which elsewhere were fading or already extinct.

Bogatyrev's monograph offers a full and systemic description of the ritual-mythological aspect of Rusyn peasant life. After a lengthy introduction in which he discusses his use of the synchronic method in his research - illustrated with numerous examples from Rusyn folklore practices and beliefs - he moves through the feasts of the Orthodox and Greek Catholic liturgical year describing in intricate detail various folk rites and beliefs connected with each of them. Finally, he scrutinizes significant moments in the peasants' lives - birth and baptism, weddings, and funerals, as well as their experience of the world of apparitions and supernatural beings - and, here again, describes intriguing folk rituals related to these.

In 1998, the first English translation of Bogatyrev's monograph under the title Vampires in the Carpathians: Magical Acts. Rites, and Beliefs in Subcarpathian Rus', was published by Columbia 
University Press's East European Monographs series under the auspices of the Carpatho-Rusyn Research Center as part of the center's own series entitled "Classics of Carpatho-Rusyn Scholarship." For this publication I reworked an initial translation by independent scholar Stephen Reynolds. For the sake of accuracy, I consulted closely both the original French publication and a subsequent Russian publication of the work which appeared in the Soviet Union in 1971 a few months before Bogatyrev's death (as Magicheskie deistvie, obriadvi verovaniia Zakarpat 'ia in a single-volume compilation of Bogatyrev's works entitled Voprosy teorii narodnogo iskusstva, Moskva, pp. 167-296). Along the way, I discovered that some individual lines and a handful of whole paragraphs had been entirely omitted from the Soviet version. It is certainly possible that the author himself might have had a hand in revising his own work, but the nature of the omissions seems to suggest that they were most probably made by a censor. What might have disturbed a Soviet censor in 1971 about Bogatyrev's scholarly observations in this study of Subcarpathian Rusyn folklore of the 1920s?

The problem passages, as it turns out, did not concern Subcarpathian Rusyn folklore per se at all. The passages which the censor found dangerous or offensive were, in fact, largely those in which Bogatyrev went beyond Rusyn folklore to reach for some kind of analogy to an item under discussion which he knew and found useful from the Russian context. These are passages, then, which might be of special interest to both Rusyn and Russian folklorists. For instance, the first omission occurs in the Introduction under a section subtitled "The currency of magical actions and rites." In discussing generally the persistence of folk beliefs into modern times, Bogatyrev notes that folk religion has remained as powerful as Christianity among all the nationalities in Russia, including Russian peasants and that, for example, there has been a "rebirth of paganism ... not only among the Cheremis [Mari] of the steppe, but even among those of the district of Krasnokoksajsk. ..." (p. 16 in the English translation; p. 182 in the Soviet version) The censor's omission begins at this point, with Bogatyrev's observation that: "This renaissance obviously occurred during the time of the Russian revolution of 1917 and the Soviet regime."

Immediately hereafter, two full paragraphs are missing from the Soviet version. In them Bogatyrev notes that "Orthodoxy and sorcery. . . form an unexpected union" throughout rural Russia, and the sorcerer or sorceress in every village is as important as the priest, the schoolmaster, and the fel'dsher [a sort of health officer]. "Formerly," Bogatyev remarks, "sorcery was forbidden and practiced only clandestinely. Now it is done openly." Sorcerers have even kept up with social progress, he states, and now record their conjurations in registers, two of which Bogatyrev says he has in his possession - "in which very old recipes based on the powers of herbs, earth, and metals are 
accompanied by bizarre conjurations."

In a third paragraph on this same page, Bogatyrev was permitted to state that he himself had observed how widespread superstitions were among "Prague actors and in various segments of the urban population - which sounds like he is referring only to Czechs, so apparently the statement was acceptable to the censor - but then the censor omitted Bogatyrev's next stunning announcement that superstitions were also widespread among the Russian working class, "from which the auditors at the Worker's University founded in Moscow by the Soviets were recruited."

Narrative endnotes attached to all of these observations are also missing from the Soviet version. In these notes, Bogatyrev drew from the observations of V. G. Tan-Bogoraz who offers examples of contemporary vestiges of old practices and beliefs in a 1924 compilation, entitled Starvi $i$ novyi byt. Tan-Bogoraz witnessed, for instance, a sorcerer's attempt to exorcise several presumably possessed women in a workers' neighborhood in Leningrad in 1923, an event which had attracted few in 1917 but drew an enormous crowd six years later. Bogatyrev adds that a priest who intervened to save the sorcerer, whom the crazed women had attempted to throw off a bridge, was himself beaten by them. It is not hard to see that the Soviet censor could not permit these observations which stood in such blatant contradiction to the enlightenment which the October Revolution of 1917 was thought to have contributed to the new Soviet man and woman.

Further in his study, Bogatyrev discusses what he calls motivated and unmotivated magical actions. In the first, practitioners feel they know and can explain why they are undertaking certain actions. In the second, practitioners are not certain why they must engage in certain actions within a particular rite or ritual, but rather "conform themselves to the details rigorously out of fear that otherwise they will destroy all the power of the magical action or will neglect some essential detail." Bogatyrev believed that the peasant population of Subcarpathian Rus' engaged largely in motivated magical actions, but that unmotivated magical actions formed the bulk of such activities on the part of "persons belonging to the middle social stratum in the towns of Russia: shopkeepers, workers, and certain professions (actors, for example) among whom, for various reasons, superstitions are widespread." He went even further to observe that the intellectual class - and this most certainly means the Russians since there was no intellectual class among the Rusyn peasantry he was studying - engages in both motivated and unmotivated magical actions, as well as turning some magic actions into games or attempting rational explanations of them. Needless to say, all of this was omitted from the Soviet version of the monograph. (p. 26 in the English; p. 193 in the Soviet version)

A final example of an omitted paragraph is found in the last section of the monograph dealing 
with "Apparitions and Supernatural Beings." Here, Bogatyrev discusses the complex art of storytelling with its interweaving of fact and fantasy, and how narrators may couch their retelling of an event in traditional tale forms in order to appeal more successfully to their audience. He illustrates this phenomenon with reference to a legend, "recently in circulation in Russia, of a communist's wife who brings a devil into the world." "This legend," he says, "is presented as an account of a real event, but in some variants exhibits the influence of folk tales." Bogatyrev draws from the research of Russian folklorist V. Smirnov who "recorded three variants of the legend at Kostroma" and observes that "augmented by current motifs, the legend spread throughout Russia and reached as far as Ukraine." As with all the material described above and omitted from the Soviet version, one can only imagine the censor's horror at this observation. (p. 143 English; p. 289 Soviet)

Unfortunately, we may not ever know exactly what Bogatyrev's role was in the production of the Soviet publication of his monograph Magical Acts and the other studies which appeared in the volume published in 1971. After losing his positions as head of the literature department at Moscow State University and the Institute of Ethnography of the Soviet Academy of Sciences and undergoing official and brutal "criticism" at the end of the 1940s, Bogatyrev by 1971 was no doubt grateful for the rehabilitation which allowed him to work again for what turned out to be only five years in the Academy of Sciences and Moscow University. The publication of his some of his scholarly research by 1971, even if scrutinized by a censor, also no doubt gratified him. We can only now hope for the publication of all of his scholarship, including an uncensored version of his fascinating monograph on Rusyn folklore. 